\title{
Maximum daily rainfall analysis at selected meteorological stations in the upper Lusatian Neisse River basin
}

\author{
Marcin Wdowikowski \\ Institute of Meteorology and Water Management - National Research Institute, Podleśna 61, 01-673 Warsaw, Poland, \\ e-mail: marcin.wdowikowski@imgw.pl
}

\author{
Bartosz Kaźmierczak \\ Wrocław University of Science and Technology, Faculty of Environmental Engineering, Wybrzeże Wyspiańskiego 27, \\ 50-370 Wrocław, Poland, e-mail: bartosz.kazmierczak@pwr.edu.pl
}

\section{Ondrej Ledvinka}

Czech Hydrometeorological Institute, Hydrological Database \& Water Balance, Na Sabatce 17, 14306 Prague 412 , Czech Republic, e-mail: ledvinka@chmi.cz

\begin{abstract}
The scope of this study was to assess the usefulness of top probability distributions to describe maximum rainfall data in the Lusatian Neisse River basin, based on eight IMWM-NRI meteorological stations. The research material was composed of 50-year precipitation series of daily totals from 1961 to 2010. Misssing measurement data were estimated using a weighted average method. Homogeneity for refilled data were investigated by precipitation double aggregation curve. Correlation between the measurement data varied from 96 to $99 \%$ and did not indicate a violation of the homogeneity of rainfall data series. Variability of recorded daily precipitation maxima were studied by linear regression and non-parametric Mann-Kendall tests. Long-term period changes at maximum rainfalls for four stations remained statistically insignificant, and for the other four were significant, although the structure of maximums was relatively similar. To describe the measured data, there were used the Fréchet, Gamma, Generalized Exponential Distribution (GED), Gumbel, Log-normal and Weibull distributions. Particular distribution parameters were estimated using the maximum likelihood method. The conformity of the analyzed theoretical distributions with measured data was inspected using the Schwarz Bayesian information criterion (BIC) and also by the relative residual mean square error (RRMSE). Among others, the Gamma, GED, and Weibull distributions fulfilled the compliance criterion for each meteorological station respectively. The BIC criterion indicated GED as the best; however differences were minor between GED on the one hand and the Gamma and Weibull distributions on the other. After conducting the RRMSE analysis it was found that, in comparison to the other distributions, GED best describes the measured maximum rainfall data.
\end{abstract}

Key words: trend analysis Mann-Kendall test, meteorological data, maximum rainfall, GED, Lusatian Neisse, IMWM-NRI, probabilistic distribution

Submitted 22 January 2016, revised 4 April 2016, accepted 24 May 2016

\section{Introduction}

For both flood protection in river basins and safe rainwater drainage in urban areas, synthetic information concerning rainfall of given duration and exceedance probability is essential for the modelling of hydrological processes. Due to the noticeable and projected climate change in recent years in Poland and Europe (IPCC 2014; Kuchar et al. 2014), the frequency of the occurrence of intense heavy rains is increasing (Kaźmierczak, Kotowski 2014). This calls for a detailed analysis of the phenomenon using a probabilistic approach. The quantitative descrip- tion of rainfall amounts is based on mathematical models which show the relation of precipitation amount $(h)$ or intensity $(I)$ to its duration $(t)$ and probability of exceedance $(p)$. These relations are often in practice presented in the form of DDF type curves (Depth-Duration-Frequency) or IDF type curves (Intensity-Duration-Frequency) for various probabilities (p) (Kyselý, Picek 2007; Kaźmieczak, Kotowski 2015). This paper represents an attempt to undertake such an analysis for the Polish part of the upper Lusatian Neisse River basin. The main scope of this study was to assess and present the usefulness of top probability distributions to describe maximum rainfall data in 
a long-term period (in this case 50 years), based on the engineering approach presented by Kotowski, Kaźmierczak and Wdowikowski in their recent papers (Kotowski et al. 2010; Kotowski, Kaźmierczak 2013; Kaźmierczak, Kotowski 2014, 2015; Wdowikowski, Kaźmierczak 2015; Kaźmierczak, Wdowikowski 2016). This paper's analysis is based on the rainfall measurement data recorded at eight Polish meteorological IMWM-NRI stations located in the upper Lusatian Neisse River basin. Moreover, the paper presents an attempt to obtain spatial information about the usefulness of one type of probability distribution at a measured rainfall data description. According to IPCC reports, long-term period changes in seasonal and annual precipitation were also detected in the Upper and Middle Odra River basin (Kaźmierczak et al. 2014), as well as in the south-west border basins (Kyselý, Picek 2007; Müller, Kaspar 2014; Ledvinka, Lamacova 2015). The transboundary dimension of this analysis, which allows the possibility of multi-unit research in the mentioned range, was another motivation for the preparation of this study.

\section{Study area and data}

\subsection{Geographical, hydrological and meteorological background}

The Lusatian Neisse River basin is located on the territory of three countries: Poland, Czechia (the Czech Republic) and Germany. The total length of the river is $251.6 \mathrm{~km}$, and it has a catchment area of $4297 \mathrm{~km}^{2}$. The headwater of the River Neisse is located on the Czech side of the Jizera Mountains, at an altitude of $635 \mathrm{~m}$ a.s.1. The river flows into the Oder at 542+400 kilometer at an altitude of $32 \mathrm{~m}$ a.s.l. near the German Ratzdorf waterlevel gauge, below the border station in Gubin (Guben). From the $54^{\text {th }} \mathrm{km}$ of its upper section to the estuary, the administrative border between the Poland Germany runs through the stream of the Neisse. In Poland, the Neisse basin covers the Lower Silesian and Lubusz voivodships; in Germany it covers the federal states of Saxony and Brandenburg. Because of the expanse of the power industry, which covers nearly $10 \%$ of Polish national needs, there are a number of hydroelectricity devices in the Lusatian Neisse River basin. The Niedów Reservoir is currently the most important hydrotechnical construction facility in the region and significantly influences the flow of the Lusatian Neisse. In terms of land use, there is the dominance of agricultural land (45\%) in the south, and forest areas (43.5\%) in the north of the river basin (Adynkiewicz-Piragas et al. 2011; Lünich et al. 2014a). Despite the relatively low percentage of urban areas $(5 \%)$ in the Neisse basin, there is a high tendency towards the occurrence of heavy rainfall and disastrous floods, which can cause severe damage (Dumieński et al. 2015).

The considerable variability of the Lusatian Neisse River basin's topography, as well as the river's significant impact on the safety of the local population, means that all three countries carry out extensive hydrological and meteorological measurement programmes based at several dozen stations in total. Collaborative research projects (such as the German-Polish NEYMO project) and the international exchange of hydrological and meteorological data for flood protection purposes are also conducted (Lünich et al. 2014a, b).

Depending on the altitude of the terrain, the average annual amount of rainfall in the Lusatian Neisse basin (for the 1971-2000 period) varied from $608 \mathrm{~mm}$ at $150 \mathrm{~m}$ a.s.1. (lowlands) to $701 \mathrm{~mm}$ at $350 \mathrm{~m}$ a.s.l. (high hills). In the mountainous upper parts of the river basin - up to $650 \mathrm{~m}$ a.s.l. (the Jizera Mountains) - the average annual precipitation was $861 \mathrm{~mm}$ (Lünich et al. 2014a). In the period 19712010 , the average annual flow rates in controlled gauges were recorded as between $6.1 \mathrm{~m}^{3} \mathrm{~s}^{-1}$ in Porajów and $28.8 \mathrm{~m}^{3}$ $\mathrm{s}^{-1}$ in Gubin (Lünich et al. 2014b). The region is dominated by rainfall floods, bringing large losses to households and agricultural crops almost every year. The largest flood hitherto took place in 2010 during the disaster at the Niedów energy reservoir dam. At that time, a flood wave that was several meters high covered the main part of the basin with water, causing huge losses in urban infrastructure (Jelonek et al. 2010). In places like Bogatynia, some of the buildings have not been restored to this day (Jelonek et al. 2010).

\subsection{Rainfall data series}

In this study, the daily precipitation totals recorded at the Institute of Meteorology and Water Management - National Research Institute (IMWM-NRI) stations between 1961 and 2010 were used. Measurements of precipitation and snow cover were taken in accordance with WMO guidelines at 6 UTC (Universal Time Coordinated), representing the aggregated value for the whole day, starting from the previous day at 6 UTC and ending at 6 UTC on the day of observation (WMO 2012; Różdżyński et al. 2015). The particular area of interest was the Polish part of the upper Lusatian Neisse River basin with its boundaries as, approximately, the meteorological stations of Sieniawka and Bogatynia in the south and Przewóz hydrological station in the north (Fig. 1). This catchment division was adopted in order to include Pieńsk and Sobolice stations in the analysis.

For the analysed period, eight meteorological stations, namely Bierna, Bogatynia, Pieńsk, Sieniawka, Sobolice, Sulików, Wyszków and Zgorzelec were studied. These sta- 


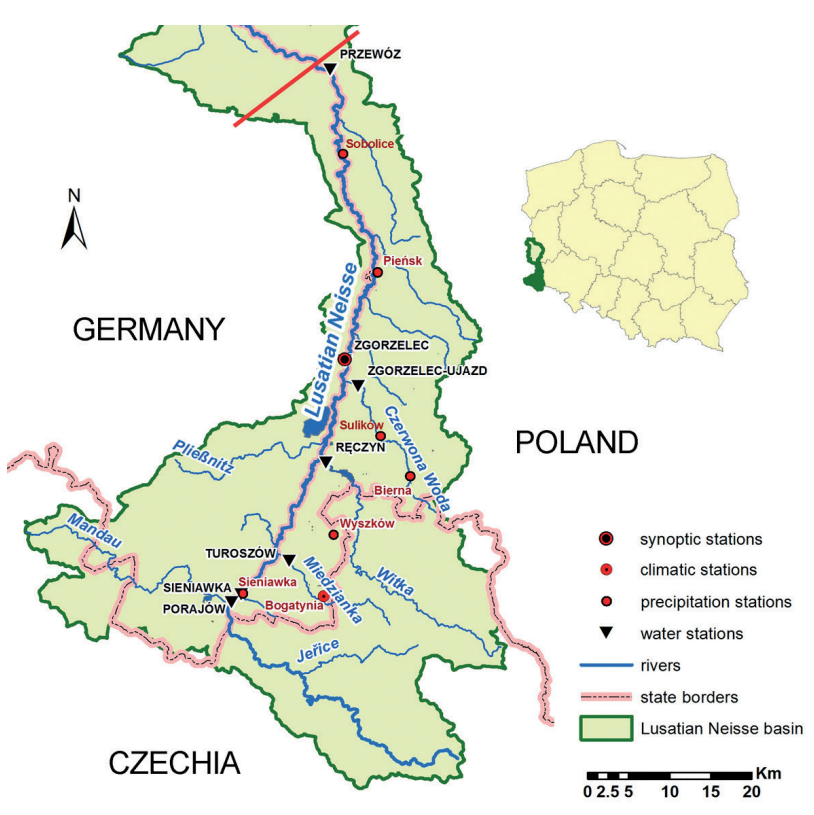

Fig. 1. Location of IMWM-NRI measuring stations; adapted from Adynkiewicz-Piragas et al. (2011)

tions perform various measuring programmes and thereby differ in their equipment and the number of parameters they measure. However, the measurement of precipitation as a basic meteorological element is performed at all stations. Detailed data on the measuring stations are summarised in Table 1.

The main type of meteorological station is the precipitation gauge, which, in addition to the rainfall amount, also observes the thickness of snow cover. At climatic stations, temperature, humidity, and wind speed and wind direction measurements are also carried out. The last type of gauge is a synoptic station, which codes the international meteorological message SYNOP within an hourly mode - this contains a great deal of information about the current state of the weather. The data from synoptic stations are used to develop daily weather forecasts (Różdżyński et al. 2015). The synoptic station in Zgorzelec was shut down in 2011 for economic reasons and because of its close proximity to the Görlitz station in Germany.
Measuring points in the analysed part of the Lusatian Neisse basin were placed at a fairly regular basis. The shortest distance in a straight line between stations was $6 \mathrm{~km}$ (neighbouring stations), and the largest did not exceed 60 $\mathrm{km}$ (stations furthest from each other). The average distance was about $20 \mathrm{~km}$.

Precipitation daily totals were measured with a Hellman ombrometer. Since 2005, the rainfall amount has been measured within a network of automatic rain gauges, mostly of the tipping-bucket type. For the purposes of the probabilistic description of maximum rainfall in the period 1961-2010 and the completeness of the series in general, the homogeneity of the data was verified and the missing values were filled in.

Due to the small number of stations, the missing daily totals were imputed using the weighted averages method (Węglarczyk 2010), where the weights for individual stations were determined numerically using the triangular irregular network (TIN) method (Szczepanek 2003). Correspondence between estimated values and measured values at the neighboring stations was assessed using correlation analysis following the construction of the precipitation double aggregation curve (PDAC) for annual values. This is a simple method that involves the comparison of two data strings generated by adding together the following elements of the sequence data in the whole set (in this case an annual precipitation cumulative curve). The method requires a reliable reference station and it is limited to the analysis of the neighbouring precipitation station only (Węglarczyk 2010). A similar procedure was used to generate rainfall data series for the period in which the measurements of precipitation were not conducted.

The analysis of one-day maximum precipitation was performed on a 50-year data series. In order to maintain the consistency of the data set (containing eight stations), the daily totals from some periods were also reconstructed for the stations at Bogatynia, Pieńsk, Sobolice and Wyszków. A comparison between stations with measured values

Table 1. Selected IMWM-NRI meteorological stations

\begin{tabular}{|c|c|c|c|c|c|c|c|}
\hline No. & Station & $\begin{array}{c}\text { Elevation } \\
{[\mathrm{m} \text { a.s.1. }]}\end{array}$ & Period & Longtitude & Latitude & Data recording & Gauge type \\
\hline 1 & Bierna & 145 & $1961-2010$ & $51^{\circ} 29^{\prime \prime}$ & $15^{\circ} 39^{\prime}$ & Man; Aut* & Precipitation \\
\hline 2 & Bogatynia & 260 & $1970-2010$ & $50^{\circ} 54^{\prime \prime}$ & $14^{\circ} 59^{\prime}$ & Man; Aut* & Climatic \\
\hline 3 & Pieńsk & 180 & $1973-2010$ & $51^{\circ} 15^{\prime}$ & $15^{\circ} 02^{\prime}$ & Man & Precipitation \\
\hline 4 & Sieniawka & 230 & $1961-2010$ & $50^{\circ} 54^{\prime \prime}$ & $14^{\circ} 51^{\prime}$ & Man; Aut* & Precipitation \\
\hline 5 & Sobolice & 150 & $1963-2010$ & $51^{\circ} 23^{\prime \prime}$ & $14^{\circ} 58^{\prime \prime}$ & Man; Aut* & Precipitation \\
\hline 6 & Sulików & 215 & $1961-2010$ & $51^{\circ} 05^{\prime}$ & $15^{\circ} 04^{\prime}$ & Man; Aut* & Precipitation \\
\hline 7 & Wyszków & 330 & $1971-2010$ & $50^{\circ} 58^{\prime \prime}$ & $15^{\circ} 00^{\prime}$ & Man & Precipitation \\
\hline 8 & Zgorzelec & 203 & $1961-2010$ & $51^{\circ} 08^{\prime \prime}$ & $15^{\circ} 02^{\prime \prime}$ & Man; Aut* & Synoptic \\
\hline
\end{tabular}

Man - manual, Aut - automatic, *since 2005 

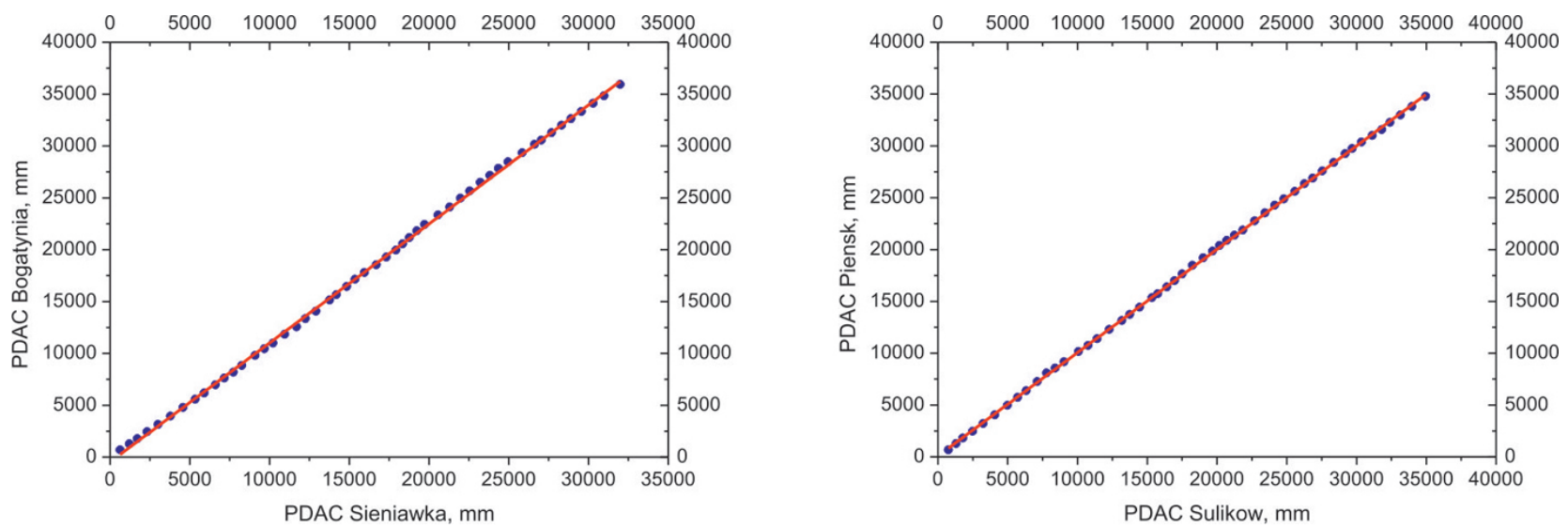

Fig. 2. Precipitation double aggregation curves $(P D A C)$ for Bogatynia-Sieniawka $\left(R^{2}=0.9996\right)$ and Pieńsk-Sulików $\left(R^{2}=0.9999\right)$ in the period 1961-2010

and those for which the imputation was performed did not indicate a violation of the homogeneity of the data series (Fig. 2). The coefficients of determination varied from 96 to $99 \%$.

To develop a maximum rainfall model based on the probability distribution, 50 major values were selected from various episodes of rain for each station. It was assumed that the minimum interval between precipitation episodes was one day. In several cases (Bogatynia: 8, Zgorzelec: 1, and Pieńsk: 10), selected extremely high rainfall values originated from the estimated parts of data series. However, even the removal of these data in the further analysis did not significantly alter either the limitation of the range of maximum values or their structure.

\section{Variability of maximum rainfall}

To evaluate the variability of daily precipitation maxima recorded in consecutive $n$ years, the ordinary least squares (OLS) linear regression and the non-parametric Mann-Kendall test were used (Kaźmierczak et al. 2014; Ay, Kisi 2015; Ledvinka, Lamacova 2015).

Results of the variability analysis for the years 1961-2010 are presented in Table 2. Statistically significant changes were considered at a confidence level greater than $95 \%$ for at least one of the applied tests (see the coloured fields in Table 2).

For the meteorological stations Bogatynia, Pieńsk, Wyszków and Zgorzelec the maximum daily totals had statistically significant increasing trends. The Bierna significance level trend is slightly below the statistic threshold value, which can be read as statistically insignificant, but the slope index is close to Bogatynia and Pieńsk, so it might be a reason why the Bierna trend could be considered significant. The linear regression confirmed significant changes in Bogatynia and Pieńsk, while the MannKendall test only did so in Zgorzelec. The greatest change (0.7 $\mathrm{mm}$ per year) occurred in the Wyszków data series according to both the linear regression and the Mann-Kendal test. The fact that the Bogatynia and Wyszków rainfall data series were replenished for the initial long-term period could lead to an underestimation of the analysed values during 1961-1971 period. However Wyszków-Bierna and Bogatynia-Sieniawka PDAC correlations did not indicate significant deviations in terms of annual precipitation. Because of the limitations of the PDAC method, Wyszków and Bogatynia data series could not be compared with each other. In the authors' opinion, when looking for the probable causes of the Wyszków daily rainfall underestimation one should take into account the diversification of the area and the diversity of other meteorological elements (such as temperature, humidity etc.) - these factors require the use of more advanced methods of daily data infilling. In terms of the main scope of the paper, Wyszków rainfall data from 1971 to 2010 are sufficient, moreover none of estimated values were included in the further analysis. The graphical interpretation of the calculations is presented in Fig. 3. Long-term period changes in Bierna, Sieniawka, Sobolice and Sulików maximum rainfall series proved to be not statistically significant, although the structure of the maxima was relatively similar.

Table 2. Trends of maximum daily precipitation totals in the long-term period 1961-2010

\begin{tabular}{|c|c|c|c|c|c|c|}
\hline \multirow{2}{*}{ Station } & \multicolumn{2}{|c|}{ OLS linear regression } & \multicolumn{2}{c|}{ Mann-Kendall test } \\
\cline { 2 - 7 } & Slope & \multicolumn{2}{|c|}{$\begin{array}{c}\text { Significance } \\
\text { level }\end{array}$} & Slope & \multicolumn{2}{|c|}{$\begin{array}{c}\text { Significance } \\
\text { level }\end{array}$} \\
\hline Bierna & 0.329 & 0.056 & $94.4 \%$ & 0.197 & 0.228 & $77.2 \%$ \\
\hline Bogatynia & 0.444 & 0.038 & $96.2 \%$ & 0.232 & 0.124 & $87.6 \%$ \\
\hline Pieńsk & 0.349 & 0.030 & $97.0 \%$ & 0.233 & 0.120 & $88.0 \%$ \\
\hline Sieniawka & -0.080 & 0.683 & $31.7 \%$ & -0.100 & 0.503 & $49.7 \%$ \\
\hline Sobolice & 0.029 & 0.826 & $17.4 \%$ & 0.023 & 0.867 & $13.3 \%$ \\
\hline Sulików & 0.122 & 0.489 & $51.1 \%$ & 0.089 & 0.738 & $26.2 \%$ \\
\hline Wyszków & 0.724 & 0.000 & $100.0 \%$ & 0.694 & 0.000 & $100.0 \%$ \\
\hline Zgorzelec & 0.229 & 0.143 & $85.7 \%$ & 0.276 & 0.032 & $96.8 \%$ \\
\hline
\end{tabular}



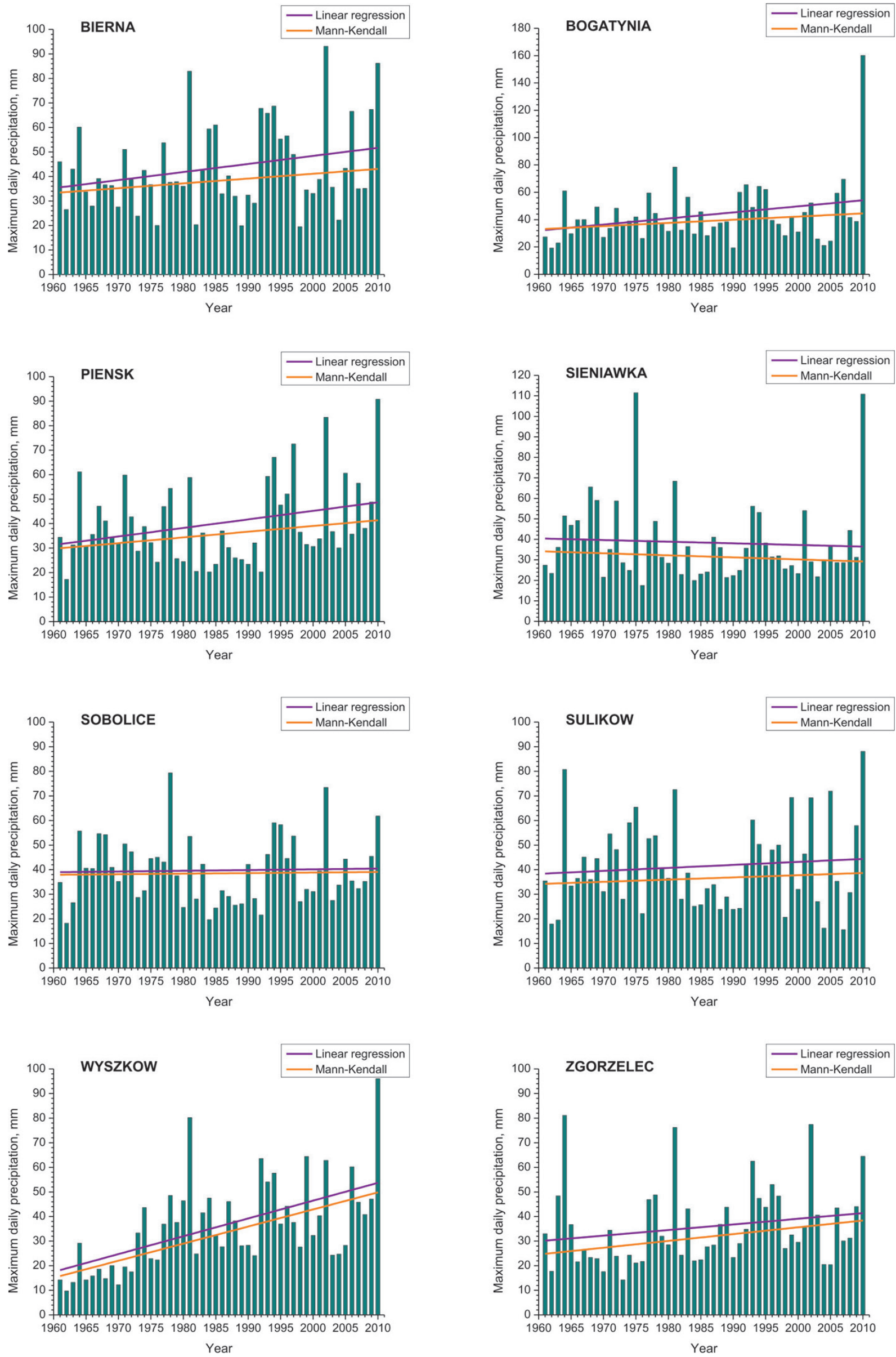

Fig. 3. Changes of maximum daily precipitation from 1961 to 2010. Bogatynia and Sieniawka Y-axies scales are different, because of the character of presented values 
It should be noted that the last year of the analysed long-term period (2010) was characterised by a very high maximum daily precipitation totals for all studied stations. Particularly noteworthy was the daily total from Bogatynia recorded on 8 August 2010, which was $160.2 \mathrm{~mm}$ (143.6 $\mathrm{mm}$ was recorded at the automatic station). It was one of the major values recorded by meteorological stations in the Lusatian Neisse basin during extreme rainfall episodes between 6 and 8 August 2010. Within two days, the amount of rainfall in the whole river basin varied from 13 to $179 \mathrm{~mm}$, causing disastrous flash floods. Apart from Poland's extreme rainfall in Bogatynia, the most intensive rainfall was recorded at Czech stations Hejnice (179.0 $\mathrm{mm}$ ) and Olivetská Hora (172.5 mm). Considerably lower rainfall was recorded at the Varnsdorf station in Czechia $(89.4 \mathrm{~mm})$, and at the Bertsdorf-Hörnitz station in Germany $(102.0 \mathrm{~mm})$. The spatial distribution of the daily values of precipitation constructed as a combination of radar and ground observations on 7 August 2010 is shown in Fig. 4. The combination of radar and ground observations was made based on methods developed and applied by the Czech Hydrometeorological Institute (CHMI) services (S̆alek 2000).

Heavy rainfall in August 2010 caused the Niedów Reservoir frontal dam to break, which resulted in a flood wave greater than 7 meters passing through the Lusatian Neisse riverbed. As well as other damage, it caused enormous losses in urban and transport infrastructure (Jelonek et al. 2010; Müller, Kaspar 2014).

\section{Maximum rainfall model}

Several steps are required for the development of a mathematical model to determine the daily precipitation amount with a given probability of non-exceedance. These include measured data preparation and processing - the selection of data series that become random variables, selection of proper probability distributions, the estimation of selected distribution parameters (e.g. shape $\alpha$, scale $\lambda$ and location $\mu$ ), the transformation of a particular distribution quantile, and the evaluation of the quality of correlation between modelled and measured rainfall data (Bartels et al. 2005; Kotowski, Kaźmierczak 2013; Kaźmierczak, Wdowikowski 2016). Methods for selecting measured data appropriate for the probabilistic determination of maximum rainfall values are described widely in the global literature - these are, namely, the annual maximum precipitation (AMP or MAP) and peak-over-threshold (POT) methods. Because many studies indicate that the AMP method provides lower maximum rainfall values, in this research the necessary data were selected using

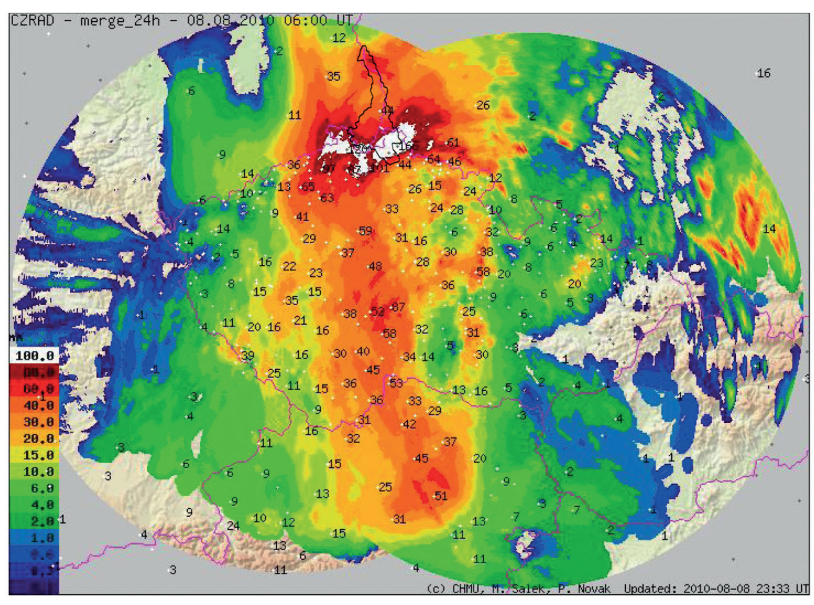

Fig. 4. Spatial distribution of daily rainfall totals - combination of radar and ground stations on 8 August 2010, 6 UTC (adapted from source: www.chmi.cz)

the POT method (Coles 2001; Kim, Zhang 2011; Onyutha 2012; Shinyie et al. 2014; Yilmaz et al. 2014; Jakubowski 2015; Wdowikowski, Kaźmierczak 2015; Kaźmierczak, Wdowikowski 2016; Wi et al. 2016). For all 8 stations the $95^{\text {th }}$ percentile was found to be appropriate as the threshold level for 24-hour POT data series. To ensure independence within the POT series, the authors required a minimum 1-day separation time between rainfall exceedances. In this study, each random sample (representing one of the eight stations) consisted of the 50 largest daily rainfall totals recorded in the long-term period from 1961 to 2010. It is worth noting that while precipitation series included data for entire years, the maximum rainfall values that are used in the rest of the paper came exclusively from the warm season (May to October). It is a characteristic feature of this region's climate that precipitation during the summer season constitutes a major portion of annual precipitation (Suligowski 2013).

Probability distributions commonly known in hydrology were used to describe the measured data: Fréchet, Gamma, Generalized Exponential Distribution (GED), Gumbel, Log-normal and Weibull (Gupta, Kundu 2007; Ben-Zvi 2009; Jakubowski 2015; Onyutha, Willems 2015; Kaźmierczak, Wdowikowski 2016). The parameters of these distributions were estimated using the maximum likelihood (ML) method. The Schwarz Bayesian information criterion (BIC; Konishi, Kitagawa 2008) and the relative mean square residual error (RRMSE; Kaźmierczak, Kotowski 2015) were used to evaluate the quality of fit of theoretical distributions to the measured data. The calculation results are shown in Tables 3 and 4 (in both cases, the smaller value of calculated statistics indicates a better fit to measured data).

The BIC criterion identified GED as the best method for describing the daily rainfall at the analysed stations. 
Table 3. Probabilistic distribution BIC values for analysed meteorological stations

\begin{tabular}{|c|c|c|c|c|c|c|}
\hline \multirow{2}{*}{ Station } & \multicolumn{7}{|c|}{ Probabilistic distribution } \\
\cline { 2 - 7 } & Fréchet & Gamma & GED & Gumbel & Log-normal & Weibull \\
\hline Bierna & 377.47 & 362.84 & 362.68 & 389.18 & 371.51 & 363.82 \\
\hline Bogatynia & 371.54 & 361.18 & 361.40 & 397.09 & 368.28 & 361.73 \\
\hline Pieńsk & 382.20 & 367.73 & 367.56 & 388.88 & 377.50 & 368.85 \\
\hline Sieniawka & 376.76 & 369.39 & 369.47 & 395.14 & 373.74 & 369.55 \\
\hline Sobolice & 365.94 & 352.81 & 352.64 & 366.52 & 361.89 & 353.78 \\
\hline Sulików & 379.53 & 370.70 & 370.61 & 384.54 & 375.95 & 371.08 \\
\hline Wyszków & 368.42 & 362.38 & 362.37 & 379.44 & 365.27 & 362.59 \\
\hline Zgorzelec & 385.72 & 368.45 & 368.15 & 391.50 & 380.52 & 370.61 \\
\hline
\end{tabular}

Table 4. Probabilistic distributions RRMSE values for analysed meteorological stations

\begin{tabular}{|c|c|c|c|c|c|c|}
\hline \multirow{2}{*}{ Station } & \multicolumn{7}{|c|}{ Probabilistic distribution } \\
\cline { 2 - 7 } & Fréchet & Gamma & GED & Gumbel & Log-normal & Weibull \\
\hline Bierna & $17.35 \%$ & $3.12 \%$ & $3.07 \%$ & $6.66 \%$ & $8.10 \%$ & $3.37 \%$ \\
\hline Bogatynia & $6.98 \%$ & $6.20 \%$ & $6.27 \%$ & $9.57 \%$ & $5.89 \%$ & $6.06 \%$ \\
\hline Pieńsk & $8.66 \%$ & $2.82 \%$ & $2.80 \%$ & $6.60 \%$ & $5.64 \%$ & $2.89 \%$ \\
\hline Sieniawka & $5.81 \%$ & $5.32 \%$ & $5.40 \%$ & $9.50 \%$ & $4.66 \%$ & $5.08 \%$ \\
\hline Sobolice & $7.01 \%$ & $2.66 \%$ & $2.66 \%$ & $4.52 \%$ & $3.18 \%$ & $2.37 \%$ \\
\hline Sulików & $8.95 \%$ & $2.32 \%$ & $2.31 \%$ & $5.68 \%$ & $4.10 \%$ & $2.29 \%$ \\
\hline Wyszków & $4.23 \%$ & $2.87 \%$ & 2.91 & $7.22 \%$ & $2.44 \%$ & $2.80 \%$ \\
\hline Zgorzelec & $13.52 \%$ & $4.61 \%$ & $4.51 \%$ & $7.07 \%$ & $8.02 \%$ & $4.76 \%$ \\
\hline
\end{tabular}

Here, the minimum value of statistics was observed for 6 of the 8 measuring stations (Bierna, Pieńsk, Sobolice, Sulików, Wyszków and Zgorzelec). For the other two stations (Bogatynia and Sieniawka) the Gamma distribution turned out to be slightly better. However, it should be noted that the differences between the GED, Weibull and Gamma distribution were not so significant.

The RRMSE criterion displayed the advantage of the GED, Weibull, Log-normal and Gamma distributions. The Weibull distribution had the smallest values, and these were observed for 3 of the 8 measuring stations (Bogatynia, Sobolice and Sulików). GED turned out to be the best for other three stations (Bierna, Pieńsk and Zgorzelec). Similar to the BIC criterion, the differences between the top three distributions were insignificant. The Fréchet and Gumbel distributions both described measured data worst, as also highlighted by the BIC and RRMSE statistics, whose values were relatively low compared to the other distributions statistics. Fréchet and Gumbel both were discordant for Bogatynia, Pieńsk, Sieniawka, Sobolice and Sulików, while the Fréchet and Log-normal distributions were both worst for Bierna and Zgorzelec. This means that the Fréchet distribution described measured data worst in all cases.

The quality of fit of each probability distribution to measured data was analysed across all eight measuring stations ( 50 values times 8 stations gave 400 data points). The results are shown as $h$ - $h$ plots (measured or empirical rainfall amount compared with modelled rainfall amount), which are also known as quantile-quantile $(q-q)$ plots (Kaźmierczak, Kotowski 2015; Onyutha, Willems 2015) in Fig. 5.

On the basis of the BIC and RRMSE criteria, GED was chosen to develop maximum daily rainfall models for the analysed measuring stations. Random variable $x$ that takes only the positive values and obys the basic two-parameter GED distribution is described by the density function with shape and scale parameters $\alpha$ and $\lambda$, respectively (1):

$$
f(x ; \alpha ; \lambda)=\alpha \lambda\left(1-e^{-x \lambda}\right)^{\alpha-1} e^{-x \lambda}, \quad \alpha, \lambda>0
$$

The density functions of the generalised exponential distribution can take different shapes depending on the $\alpha$ value. Considering the lower limitation (i.e. location) parameter $(\mu<x)$ at the density function (1), the GED quantile has the form (Gupta, Kundu 2007):

$$
x=\mu-\frac{1}{\lambda} \ln \left(1-(1-p)^{1 / \alpha}\right)
$$

where $p$ is the probability of exceeding the rainfall. The detailed transformation process can be found in Gupta and Kundu (2007) or in Kaźmierczak and Kotowski (2015). The ML parameters of GED obtained by the numerical 
Fréchet
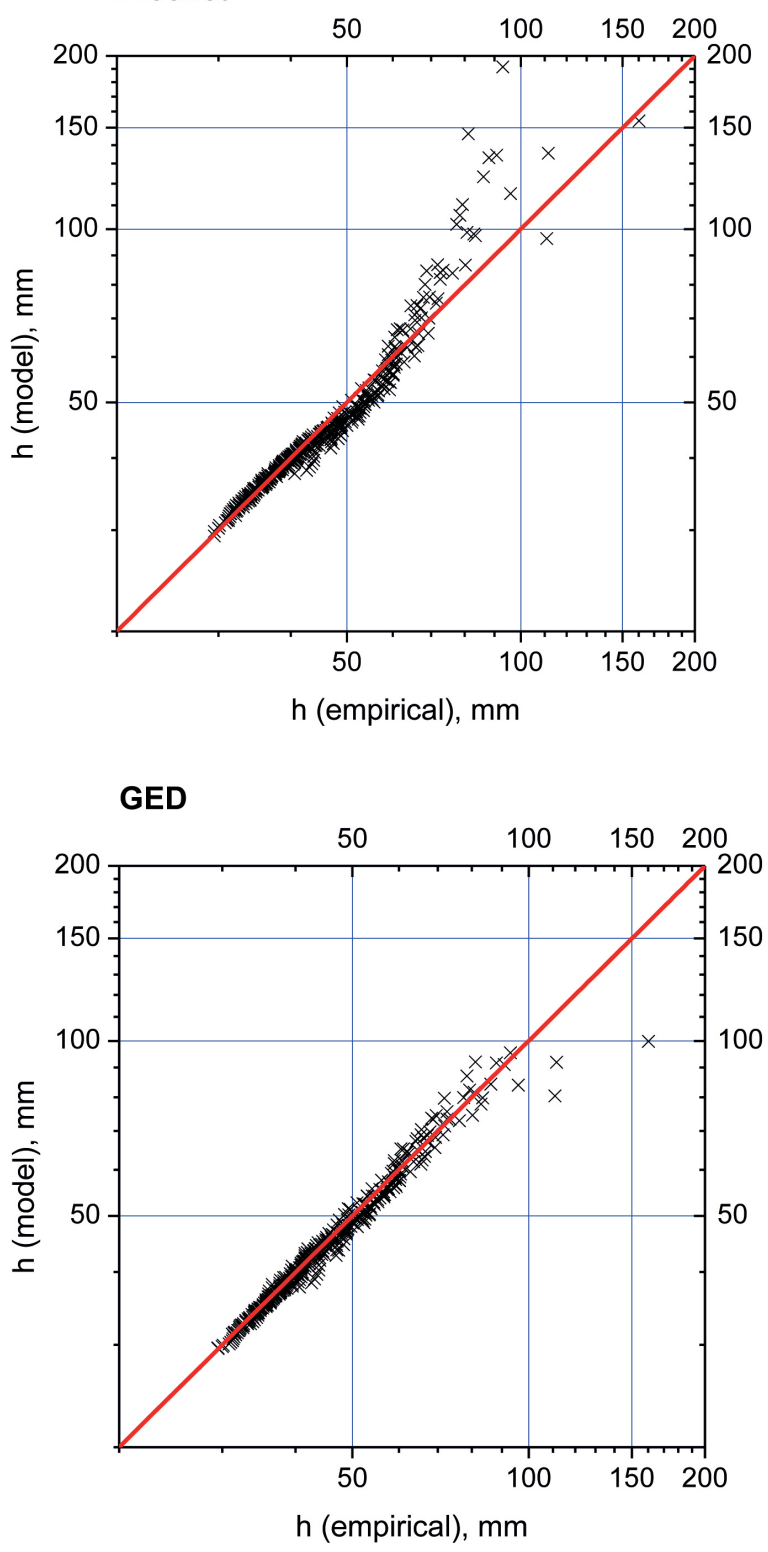

\section{Log-normal}

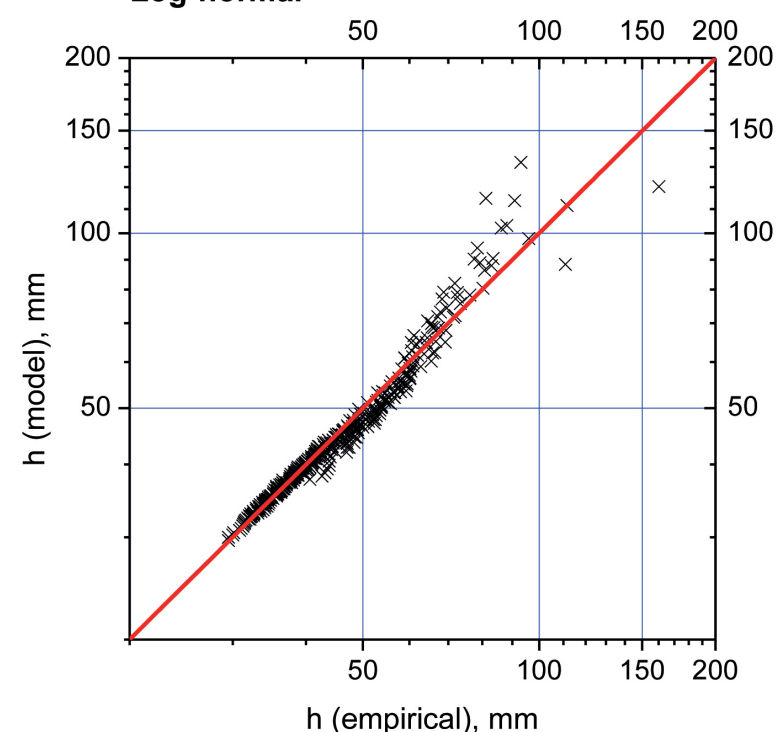

\section{Gamma}

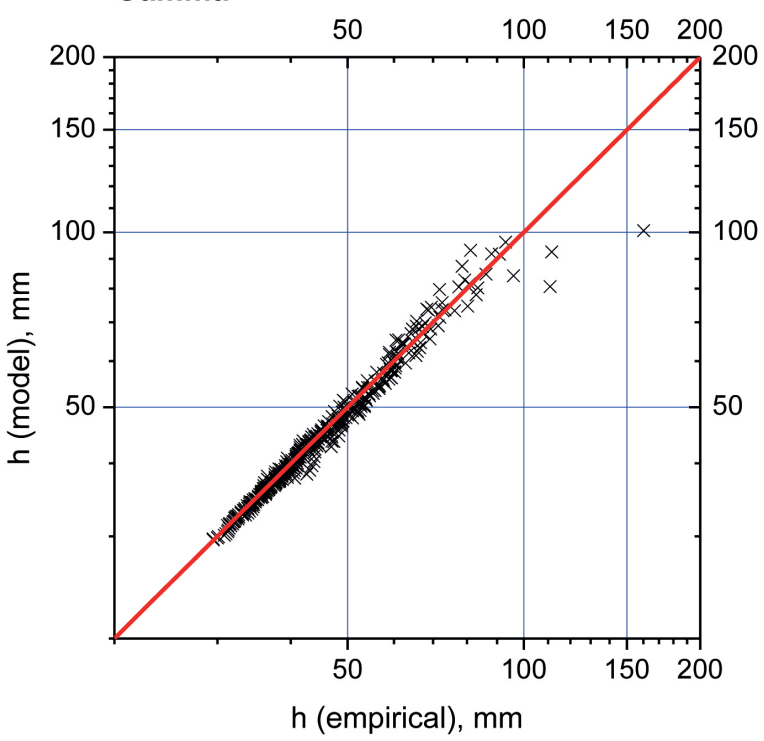

\section{Gumbel}

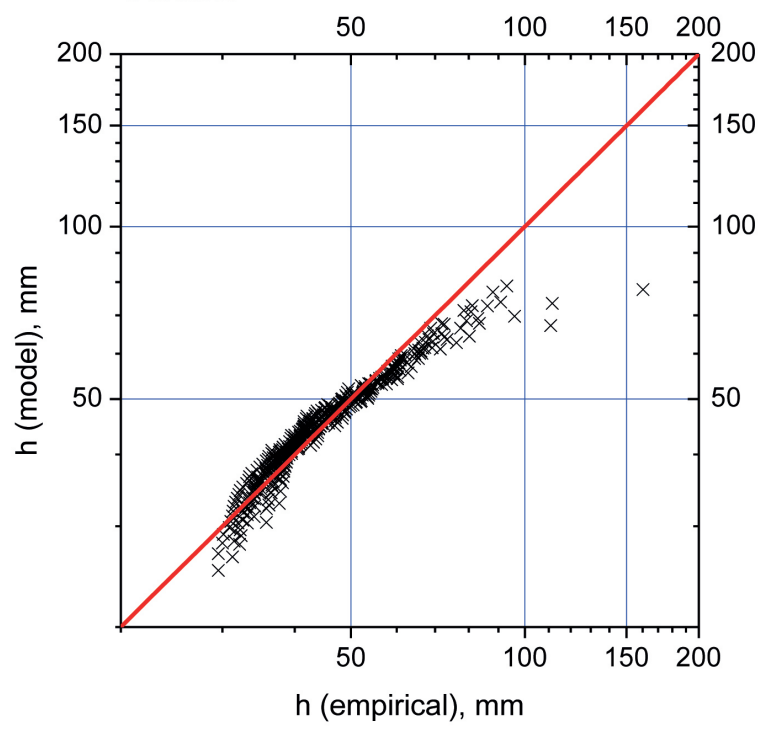

Weibull

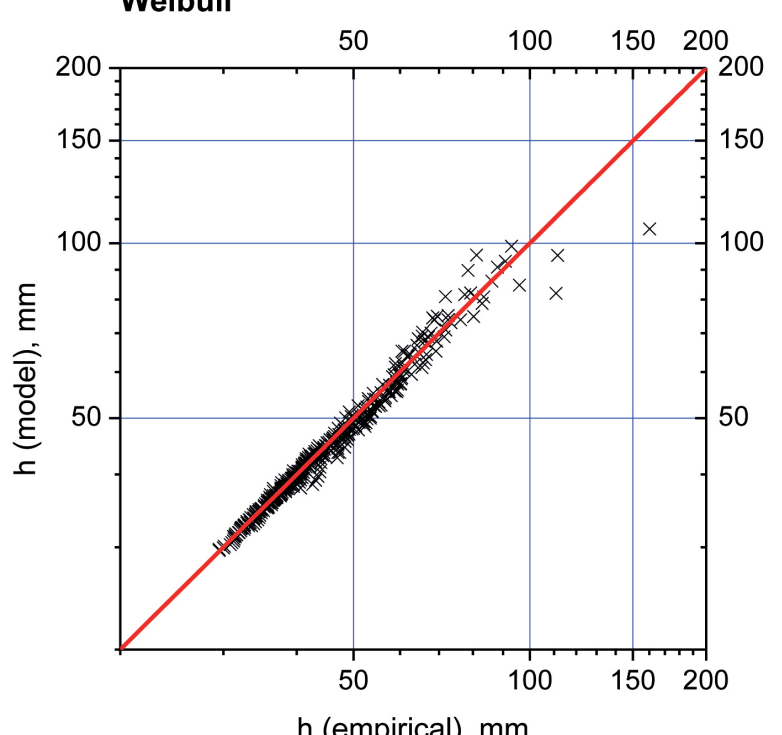

Fig. 5. Correlation between probability distribution of modelled and measured (empirical) rainfall data expressed as $h$ - $h$ plots; also known as quantile-quantile $(q-q)$ plots 
maximisation of the log-likelihood function are summarised in Table 5.

Amounts of precipitation at a given probability exceedance level $p$ were calculated on the basis of the developed model for all the analysed daily rainfall measuring stations. Table 6 shows the resulting quantiles (theoretical rainfall amounts) calculated according to (2) and corresponding to the selected probability of exceedance from $p=0.10$ to $p=0.01$ (daily amount occurrence from once every 10 years to once every 100 years, respectively).

A GED distribution-based relationship between the daily rainfall amount and rainfall at a given probability exceedance level gave comparable results for all of the analysed stations. For example, about 100-year rainfall total $(p=0.01)$ ranged from $93.3 \mathrm{~mm}$ for Wyszków to 112.1 $\mathrm{mm}$ for Bogatynia. The probabilistic approach indicated that the extreme rainfall value $(160.2 \mathrm{~mm})$ that was recorded on 7 August 2010 at the Bogatynia station had a probability of exceedance $p=0.001$ (1000-year rainfall).

Table 5. GED parameters for analysed meteorological stations

\begin{tabular}{|c|c|c|c|}
\hline \multirow{2}{*}{ Station } & \multicolumn{3}{|c|}{ Distribution parameter } \\
\cline { 2 - 4 } & $\alpha$ & $\lambda$ & $\mu$ \\
\hline Bierna & 0.712 & 0.062 & 37.6 \\
\hline Bogatynia & 0.616 & 0.054 & 35.7 \\
\hline Pieńsk & 0.744 & 0.062 & 32.1 \\
\hline Sieniawka & 0.736 & 0.060 & 31.2 \\
\hline Sobolice & 0.805 & 0.077 & 34.0 \\
\hline Sulików & 0.873 & 0.068 & 36.1 \\
\hline Wyszków & 0.859 & 0.073 & 32.3 \\
\hline Zgorzelec & 0.685 & 0.057 & 29.5 \\
\hline
\end{tabular}

Table 6. Modelled rainfall values corresponding to desired probabilities for analysed meteorological stations

\begin{tabular}{|c|c|c|c|c|c|}
\hline \multirow{2}{*}{ Station } & \multicolumn{5}{|c|}{ Probability } \\
\cline { 2 - 6 } & $p=0.10$ & $p=0.05$ & $p=0.04$ & $p=0.02$ & $p=0.01$ \\
\hline Bierna & 69.6 & 80.6 & 84.2 & 95.3 & 106.4 \\
\hline Bogatynia & 70.0 & 82.5 & 86.6 & 99.3 & 112.1 \\
\hline Pieńsk & 64.8 & 75.8 & 79.4 & 90.5 & 101.6 \\
\hline Sieniawka & 64.8 & 76.2 & 79.9 & 91.4 & 102.9 \\
\hline Sobolice & 61.2 & 70.2 & 73.1 & 82.0 & 91.0 \\
\hline Sulików & 68.1 & 78.2 & 81.5 & 91.7 & 101.8 \\
\hline Wyszków & 61.9 & 71.3 & 74.4 & 83.8 & 93.3 \\
\hline Zgorzelec & 63.7 & 75.6 & 79.5 & 91.6 & 103.7 \\
\hline
\end{tabular}

\section{Discussion and conclusions}

In the present study, maximum rainfall totals from eight IMWM-NRI meteorological stations located in the
Polish part of the upper Lusatian Neisse basin (Bierna, Bogatynia, Pieńsk, Sieniawka, Sobolice, Sulików, Wyszków and Zgorzelec) were analysed.

Firstly, maximum daily precipitation trends were investigated using simple linear regression and the Mann--Kendall test for the long-term period of 1961 to 2010. Statistically significant increases in maximum daily totals were found at four of the measuring points (Bogatynia, Pieńsk, Wyszków and Zgorzelec), where only those changes whose statistics fell outside the $95 \%$ confidence interval for either of the two methods were considered significant. In recent years, similar increasing trends have been observed in many regions of Europe (De Luís et al. 2000; Hänsel et al. 2009; Longobardi, Villani 2010). Undoubtedly, research in this area should be continued in the future in order to confirm trends in the maximum rainfall amounts over a longer period of time.

In the latter part of the study, the suitability of selected probability distributions commonly used in watershed hydrology and urban stormwater hydrology was investigated to describe the measured rainfall data at the analysed stations. In this paper, the Fréchet, Gamma, GED, Gumbel, Log-normal and Weibull distributions were tested. For each meteorological station, the parameters of distributions were estimated by the maximum likelihood method, and then the results were compared using the Schwarz BIC information criterion and the relative mean square residual error respectively. The proposed criteria allowed GED to be chosen as a probability distribution that best described the measured data. However, the qualitative differences between the GED, Gamma and Weibull distributions were minor and were considered insignificant. Compared with the remaining candidates, the Log-normal distribution proved to be moderately appropriate for fitting with regard to the applied BIC and RRMSE criteria. On the other hand, the Fréchet and Gumbel distributions described the measured rainfall data worst in terms of the selected criteria. Based on the GED distribution, maximum daily rainfall models at given probability exceedance levels were developed for all the eight measuring stations analysed.

The results for the Gumbel distribution in the Poland's Lusatian Neisse River basin are fairly surprising when we consider that this probability distribution was employed in maximum rainfall modelling for the German KOSTRA atlas (Bartels et al. 2005). The research done by Kaźmierczak and Kotowski (2015) in Wrocław, as well as the studies conducted by Wdowikowski and Kaźmierczak (2015) and Kaźmierczak and Wdowikowski (2016) in Legnica, show that GED, and not the Gumbel distribution, best describes the maximum rainfall data measured at IMWM-NRI meteorological stations (see also Bartels et al. 2005). This fact 
further opens questions as to the suitability of the Gumbel distribution in other parts of Poland or even in neighbouring countries.

Without exception, all the studied probability distributions poorly describe the highest values of rain - GED, Gamma, Log-normal and Weibull at around $90 \mathrm{~mm}$, and the rest at around $60 \mathrm{~mm}$. This situation was confirmed in studies such as the KOSTRA atlas, as well as those from Legnica and Wrocław. For these cases, the authors suggest describing the maximum rainfall of a given duration and the probability of occurrence using two or three curves based on different distributions.

Bibliography

Adynkiewicz-Piragas M., Kryza J, Krasowski W., Lejcuś I., Lisowski J., Otop I., Zdralewicz I., 2011, Lignite mining in the Lusatian Neisse River basin, Detailed model based impact studies on water resources, IMGW-PIB, Warszawa, 60 pp.

Ay M., Kisi O., 2015, Investigation of trend analysis of monthly total precipitation by an innovative method, Theoretical and Applied Climatology, 120 (3), 617-629, DOI: 10.1007/ s00704-014-1198-8

Bartels H., Dietzer B., Malitz G., Albrecht F.M., Guttenberger J., 2005, KOSTRA DWD-2000 Starkniederschlagshöhen für Deutschland (1951-2000), Deutscher Wetterdienst, Offenbach, $53 \mathrm{pp}$

Ben-Zvi A., 2009, Rainfall intensity-duration-frequency relationships derived from large partial duration series, Journal of Hydrology, 367 (1-2), 104-114, DOI: 10.1016/j.jhydrol.2009.01.007

Coles S., 2001, An introduction to statistical modeling of extreme values, Springer Series in Statistics, Springer-Verlag London, 209 pp.

De Luís M., Raventós J., Gonzáles-Hidalgo J.C., Sánchez J.R., Cortina J., 2000, Spatial analysis of rainfall trends in the region of Valencia (East Spain), International Journal of Climatology, 20 (12), 1451-1469, DOI: 10.1002/1097-0088(20 0010)20:12<1451::AID-JOC547>3.0.CO;2-0

Dumieński G., Pasiecznik-Dominiak A., Tiukało A., 2015, Social-economical assessment of Polish communities to flood threat (in Polish), [in:] Interdyscyplinarne zagadnienia w inżynierii i ochronie środowiska, Tom 6, A. Kotowski, K. Piekarska, B. Kaźmierczak (eds.), Oficyna Wydawnicza Politechniki Wrocławskiej, Wrocław, 100-125

Gupta R.D., Kundu D., 2007, Generalized exponential distribution: existing results and some recent developments, Journal of Statistical Planning and Inference, 137 (11), 3537-3547, DOI: 10.1016/j.jspi.2007.03.030

Hänsel S., Petzold S., Matschullat J., 2009, Precipitation trend analysis for Central Eastern Germany 1851-2006, [in:] Bioclimatology and Natural Hazards, K. Střelcová, J. Škvarenina, M. Blaženec (eds.), International Scientific Conference, Pol'ana nad Detvou, Slovakia, 29-38

IPCC, 2014, Climate Change 2014: Impacts, Adaptation, and Vulnerability, Part B: Regional Aspects, Europe, R. Sari Kovats, Riccardo Valentini (eds.), IPCC, Geneva, Switzerland, 1267-1326, available at: http://www.ipcc.ch/pdf/assessmentreport/ar5/wg2/WGIIAR5-Chap23_FINAL.pdf (data access 01.06.2016)

Jakubowski W., 2015, On the instabilities of estimated distributions of the POT (Peak Over Threshold) low flow characteristics, Meteorology Hydrology and Water Management, 3 (2), 33-38

Jelonek L., Wrzeszcz L., Zawiślak J., Walther P., Winkler U., Wortha S., Srejber J., Petr J., 2010, Hochwasser im Einzugsgebiet der Lausitzer Neiße, 7-10 August, Polnisch-DeutschTschechische Expertengruppe, Wrocław-Prague-Dresden, 50 pp.

Kaźmierczak B., Kotowski A., 2014, The influence of precipitation intensity growth on the urban drainage systems designing, Theoretical Applied Climatology, 118 (1), 285-296, DOI: $10.1007 / \mathrm{s} 00704-013-1067-\mathrm{x}$

Kaźmierczak B., Kotowski A., 2015, The suitability assessment of a generalized exponential distribution for the description of maximum precipitation amounts, Journal of Hydrology, 525, 345-351, DOI: 10.1016/j.jhydrol.2015.03.063

Kaźmierczak B., Kotowski A., Wdowikowski M., 2014, Trend analysis of annual and seasonal precipitation amounts in the Upper Odra catchment (in Polish), Ochrona Środowiska, 36(3), 49-54

Kaźmierczak B., Wdowikowski M., 2016, Maximum rainfall model based on archival pluviographic records - case study for Legnica (Poland), Periodica Polytechnica Civil Engineering, 8341, 1-8, DOI: 10.3311/PPci.8341

Kim D., Zhang J., 2011, Differential ability of annual maximum series and peaks-over-threshold series to detect trend in extreme daily rainfall - a simulation approach, $19^{\text {th }}$ Conference on Applied Climatology, 17-21 July, Asheville, USA, available at https://ams.confex.com/ams/19Applied/webprogram/ Paper190504.html (data access 01.06.2016)

Konishi S., Kitagawa G., 2008, Information criteria and statistical modeling, Springer Series in Statistics, Springer-Verlag New York, USA, 276 pp., DOI: 10.1007/978-0-387-71887-3

Kotowski A., Kaźmierczak B., 2013, Probabilistic models of maximum precipitation for designing sewerage, Journal of Hydrometeorology, 14 (6), 1958-1965, DOI: 10.1175/JHMD-13-01.1

Kotowski A., Kaźmierczak B., Dancewicz A., 2010, The modelling of precipitations for the dimensioning of sewage systems (in Polish), Studia z Zakresu Inżynierii, 68, 170 pp.

Kuchar L., Szalińska W., Iwański S., Jelonek L., 2014, A modeling framework to assess the impact of climate change on 
a river runoff, Meteorology Hydrology and Water Management, 2 (2), 49-64

Kyselý J., Picek J., 2007, Regional growth curves and improved design value estimates of extreme precipitation events in the Czech Republic, Climate Research, 33 (3), 243-255, DOI: $10.3354 / \mathrm{cr} 033243$

Ledvinka O., Lamacova A., 2015, Detection of field significant long-term monotonic trends in spring yields, Stochastic Environmental Research and Risk Assessment, 29 (5), 14631484, DOI: 10.1007/s00477-014-0969-1

Longobardi A., Villani P., 2010, Trend analysis of annual and seasonal rainfall time series in the Mediterranean area, International Journal of Climatology, 30 (10), 1538-1546, DOI: 10.1002/joc.2001

Lünich K., Pluntke T., Niemand C., Adynkiewicz-Piragas M., Zdralewicz I., Otop I., Miszuk B., Kryza J., Lejcuś I., Strońska M., 2014a, Lusatian Neisse - The climate and characteristics of the region (in Polish), Sächsisches Landesamt für Umwelt, Landwirtschaft und Geologie, Dresden, 75 pp.

Lünich K., Prasser M., Niemand C., Adynkiewicz-Piragas M., Zdralewicz I., Otop I., Miszuk B., Kryza J., Lejcuś I., Strońska M., 2014b, Lausitzer Neiße - Wasserressourcen in der Region, Sächsisches Landesamt für Umwelt, Landwirtschaft und Geologie, Dresden, 137 pp.

Müller M., Kaspar M., 2014, Event-adjusted evaluation of weather and climate extremes, Natural Hazards and Earth System Sciences, 14, 473-483, DOI: 10.5194/nhess-14-473-2014

Onyutha C., 2012, Statistical modelling of FDC and return periods to characterise QDF and design threshold of hydrological extremes, Journal of Urban and Environmental Engineering, 6 (2), 132-148, DOI: 10.4090/juee.2012.v6n2.132148

Onyutha C., Willems P., 2015, Empirical statistical characterization and regionalization of amplitude-duration-frequency curves for extreme peak flows in the Lake Victoria basin, East Africa, Hydrological Sciences Journal, 60 (6), 9971012, DOI: $10.1080 / 02626667.2014 .898846$

Różdżyński K., Jurczak K., Grzelak-Agaciak E., Górka A., Trzebunia J., Suchecki S., Lech H., Kieloch B., Stepko W., Derek P., Kamińska M., Ragin G., Woźniak Ł., Letachowicz J., 2015, Instructions for the meteorological stations (in Polish), IMGW-PIB, Warszawa, 442 pp.
Salek M., 2000, The radar and raingauge merge precipitation estimate of daily rainfall - first results in the Czech Republic, Physics and Chemistry of the Earth (B), 25 (10-12), 977-979, DOI: 10.1016/S1464-1909(00)00136-2

Shinyie W.L., Ismail N., Jemain A.A., 2014, Semi-parametric estimation based on second order parameter for selecting optimal threshold of extreme rainfall events, Water Resources Management, 28 (11), 3489-3514, DOI: 10.1007/s11269014-0684-1

Suligowski R., 2013, The spatial distribution of probable maximum precipitation (PMP) over the Kielce Upland in one-day and multi-days intervals, Meteorology Hydrology and Water Management, 1 (1), 39-44

Szczepanek R., 2003, Spatio-temporal structure of precipitation in the mountains catchment (in Polish), PhD thesis, Cracow University of Technology, Kraków, 138 pp., available at http:// holmes.iigw.pl/ rszczepa/publikacje/doktorat_R.Szczepanek.pdf (data access 01.06.2016)

Wi S., Valdés B.J., Steinschneider S., Kim T.-W., 2016, Non-stationary frequency analysis of extreme precipitation in South Korea using peaks-over-threshold and annual maxima, Stochastic Environmental Research and Risk Assessment, 30 (2), 583-606, DOI: 10.1007/s00477-015-1180-8

Węglarczyk S., 2010, Statistics in environmental engineering (in Polish), Cracow University of Technology, Kraków, 375 pp.

Wdowikowski M., Kaźmierczak B., 2015, Comparison of methods to select the maximum values to develop a mathematical model of extremely high rainfall in the river basin, Acta Hydrologica Slovaca, 16, 190-198

WMO, 2012, Guide to meteorological instruments and methods of observation, WMO-No. 8, 2008 edition, updated in 2010, 151-173

Yilmaz A.G., Hossain I., Perera B.J.C., 2014, Effect of climate change and variability on extreme rainfall intensity-frequency-duration relationships: a case study of Melbourne, Hydrology and Earth System Sciences, 18, 4065-4076, DOI: 10.5194/hess-18-4065-2014 